\title{
Acrodermatitis enteropathica with normal serum zinc levels: diagnostic value of small bowel biopsy and essential fatty acid determination
}

\author{
D MACK, B KOLETZKO, S CUNNANE, E CUTZ, AND A GRIFFITHS \\ Division of Pediatric Gastroenterology, Clinical Nutrition and Pathology, Department of Pediatrics, The \\ Hospital for Sick Children and the Department of Nutritional Sciences, University of Toronto, Toronto, \\ Ontario, Canada
}

SUMMARY We report a patient with acrodermatitis enteropathica and a normal serum zinc level in whom the diagnosis was confirmed by plasma phospholipid fatty acid and a small bowel biopsy response to oral zinc therapy. Acrodermatitis enteropathica is a rare autosomal recessive condition of zinc deficiency characterised by chronic diarrhoea associated with failure to thrive, periorificial dermatitis and alopecia, susceptibility to infections and behavioural changes.' Diagnosis is usually established by reduced serum zinc levels (classical acrodermatitis enteropathica). Paneth cell abnormalities on electron microscope of a small bowel biopsy can be supportive. ${ }^{2} \mathrm{~A}$ few cases with the typical picture of acrodermatitis enteropathica without hypozincaemia (variant acrodermatitis enteropathica) have been described. ${ }^{34}$ The diagnosis of variant acrodermatitis enteropathica to date has been based on an entirely empiric, but nonetheless convincing clinical response to oral zinc therapy. Laboratory aids to diagnosis have been lacking.

\section{Case history}

A boy, born at 37 weeks gestation to unrelated Caucasian parents, was fed a cow's milk formula $\left(\right.$ Similac $\left.^{\circledR}\right)$ from birth. From two weeks of age stools were consistently loose, frequent (six to 10/day) and foul smelling despite several formula changes (Isomil $^{\circledR}$, Similac $^{\circledR}$, Carnation $^{\circledR}$, Nutramigen $^{\circledR}$ ). The child was noted to be irritable and hungry. Despite reported high energy intakes, weight gain was poor and he crossed weight percentiles (50th at birth, 25th at one month, 10th at two months and thereafter). A perianal rash had been unresponsive to various topical treatments. Repeated stool testing by the patient's physician failed to reveal pathogens.

On admission to the Hospital for Sick Children at five months of age, the infant weighed $6 \cdot 37 \mathrm{~kg}(10 \mathrm{th}$

Address for correspondence: Dr Anne Griffiths, Division of Gastroenterology, Department of Pediatrics. The Hospital for Sick Children. 5.55 University Avenue. Toronto. Ontario. Canada M56; IX8.

Accepted for publication 9 February 1989 percentile) and the length was $64 \mathrm{~cm}$ (25th percentile). Physical examination revealed an irritable infant with circumscribed perianal ulceration (Fig. 1), sparse fine hair and ridging of the nails. Stools were loose with mucus.

Intakes of Nutramigen ${ }^{\circledR}$ in hospital averaged 115 $\mathrm{kcal} / \mathrm{kg} /$ day $(3 \cdot 1 \mathrm{~g}$ protein $/ \mathrm{kg} /$ day, linoleic acid 18 $\mathrm{cal} \%$ ). Weight increased by only $50 \mathrm{~g}$ over a two week period of investigations.

Laboratory evaluation revealed a haemoglobin of $97 \mathrm{~g} / \mathrm{l}$. Iron status was marginally low (serum iron $4 \mu \mathrm{mol} / \mathrm{l}$ (normal 5-13 $\mu \mathrm{mol} / \mathrm{l}$ ), iron binding capacity $54 \mu \mathrm{mol} / \mathrm{l}$ (normal 11-31 $\mu \mathrm{mol} / \mathrm{l})$ ). White blood cell counts (WBC) and differentials were obtained every second day. White blood cells ranged from 3.4$7 \cdot 5 \times 10^{4}$ cells $/$. Absolute neutropenia was observed three times $\left(0.92,1.25\right.$ and $0.37 \times 10^{\circ}$ cells $\left./ 1\right)$. On three determinations, normal values were obtained for serum zinc $(15.3,20.5$ and $20.5 \mu \mathrm{mol} / 1$; normal $11.5-22 \cdot 2 \mu \mathrm{mol} / \mathrm{l})$ and alkaline phosphatase (283, 274 and $274 \mathrm{U} / \mathrm{l}$; normal for boys, $<1$ year old 175 $600 \mathrm{U} / \mathrm{l})$. Serum carotene was low $(0.3 \mu \mathrm{mol} / \mathrm{l}$; normal 0.9-3.7 $\mu \mathrm{mol} / \mathrm{l})$. Vitamin $\mathrm{A}$ and $\mathrm{E}$ levels were 


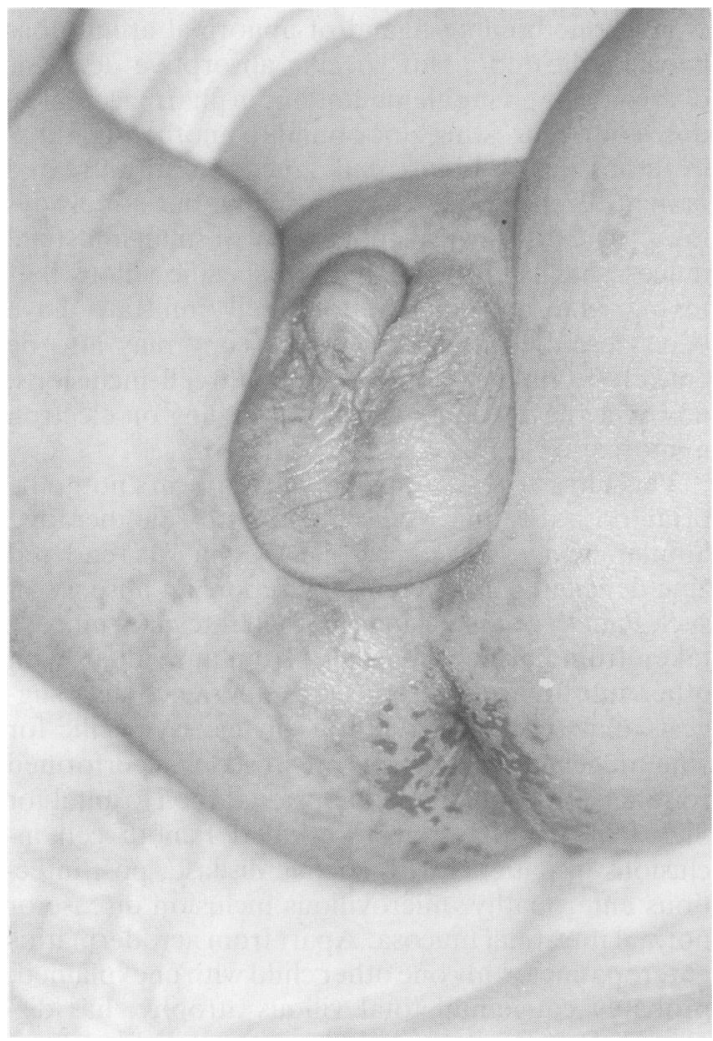

Fig. 1 Perianal rash before zinc therapy.

Table Preprandial plasma phospholipid composition during zinc therapy

\begin{tabular}{|c|c|c|c|c|}
\hline $\begin{array}{l}\text { Fatty acids } \\
(\% w t / w t)\end{array}$ & $\begin{array}{l}\text { Start of } \\
\text { zinc }\end{array}$ & $\begin{array}{l}\text { After } \\
5 \text { days }\end{array}$ & $\begin{array}{l}\text { After } \\
32 \text { days }\end{array}$ & $\begin{array}{l}\text { Controls } \\
\text { (mean }(S D))\end{array}$ \\
\hline Linoleic (18:2n-6) & $15 \cdot 3$ & $27 \cdot 1$ & $23 \cdot 7$ & $20 \cdot 7(3 \cdot 5)$ \\
\hline $\begin{array}{l}\text { Dihomo-gamma- } \\
\text { linolenic } \\
(20: 3 n-6)\end{array}$ & 1.5 & 4.4 & 4.6 & $2.7(0.8)$ \\
\hline $\begin{array}{l}\text { Arachidonic } \\
(20: 4 n-6)\end{array}$ & $4 \cdot 8$ & $10 \cdot 9$ & $13 \cdot 1$ & $7 \cdot 5(2 \cdot 4)$ \\
\hline $\begin{array}{l}\text { n-6-Docosapen- } \\
\text { taenoic } \\
(22: 5 n-6)\end{array}$ & ND & $(1.7$ & $1 \cdot 0$ & $0 \cdot 6(0 \cdot 4)$ \\
\hline $\begin{array}{l}\text { Alpha-linolenic } \\
(18: 3 n-3) \\
\text { n-3-Docosapen- } \\
\text { taenoic }\end{array}$ & ND & NI) & $0 \cdot 2$ & $(0 \cdot 1(0 \cdot 1)$ \\
\hline $\begin{array}{l}\text { Docosahexaenoic } \\
(22: 6 n-3)\end{array}$ & 0.4 & 0.8 & 1.0 & $1 \cdot 7(1 \cdot(0)$ \\
\hline
\end{tabular}

Reference values for plasma phospholipid fatty acids were obtained from five healthy, well nourished infants aged 5 (1) months $(\mathrm{M}(\mathrm{SD})) . \mathrm{ND}=$ not detectable. normal. No pathogens were isolated from the stool. Normal results were obtained for serum albumin, immunoglobulins, anti-white cell antibodies, serum trypsinogen, faecal fat excretion as a percentage of intake, sweat chlorides and a chest radiograph.

Blood for preprandial plasma phospholipid composition (taken four to six hours from the previous feeding) revealed low values for linoleic acid and
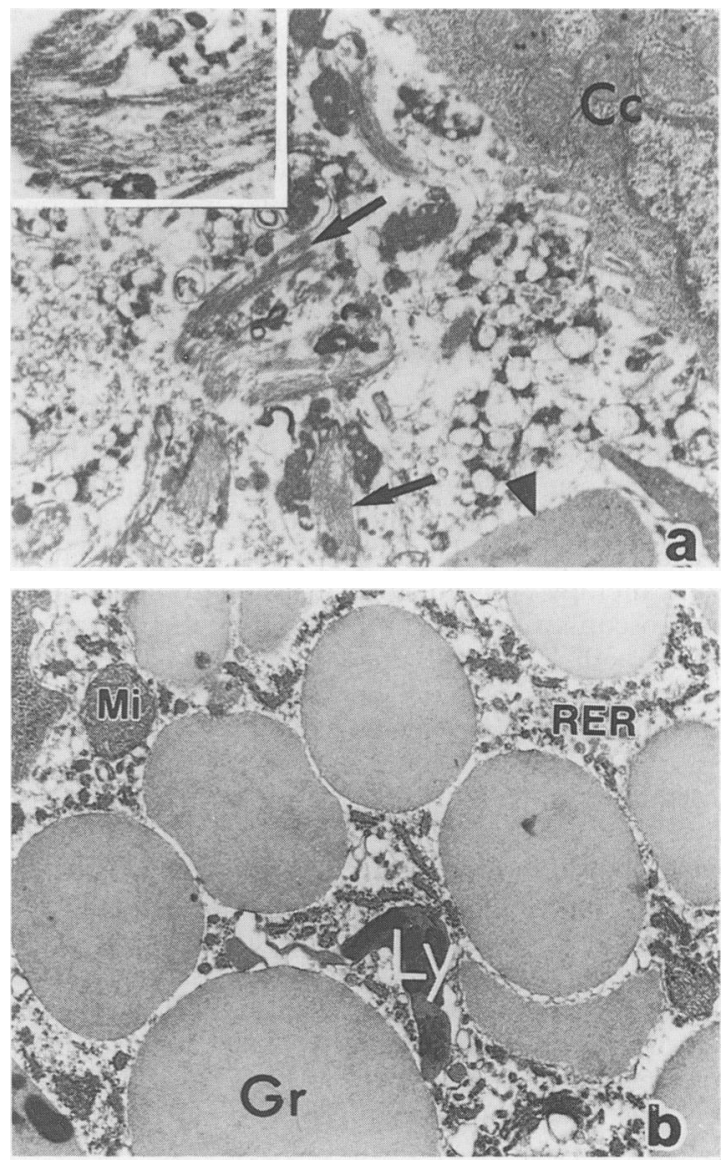

Fig. 2 (a) Electron micrograph of Paneth cell from initial biopsy of small intestine (before zinc therapy). A portion of (ytoplasm with several filamentous inclusions (arrows) and one relatively normal cytoplasmic granule (arrowhead) with homogeneous moderately electron dense matrix. Other cytoplasmic organelles show degenerative changes, in contrast with adjacent crypt cell $\left(C_{1}\right)$ which is well preserved. Insert: Close up of filamentous inclusion with fine fibrillar matrix.

Fig. 2 (b) Electron micrograph of Paneth cell in biopsy of small intestine after one month on oral zinc treatment. The cytoplasmic granules (Gr) as well as mitochondria (Mi) and rough endoplasmic reticulum (RER) show normal ultrastructural features. Ly-lysosome like inclusion. 
for major long chain polyunsaturated metabolites (20:3n-6, 20:4n-6, 22:5n-3, 22:6n-3) (Table).

Light microscopy of a small bowel biopsy revealed focal areas of villous shortening with mild crypt lengthening and a slight increase in mixed inflammatory cell infiltrate in the lamina propria. Electron microscopy revealed numerous pleomorphic filamentous inclusion bodies typical of acrodermatitis enteropathica in the cytoplasm of most of the Paneth cells² (Fig. 2a).

Based on a tentative diagnosis of variant acrodermatitis enteropathica, treatment with zinc sulphate (30 mg elemental zinc per day) by mouth was started. The patient's mood improved within four days, the perianal rash disappeared by two weeks. By one month the patient had gained $400 \mathrm{~g}$, was passing one semiformed stool on alternate days, and had normal scalp, hair and nails. Neutrophil counts became consistently normal. Serum alkaline phosphatase had risen to $358 \mathrm{U} / \mathrm{l}$.

Preprandial plasma phospholipid essential fatty acids increased within five days of therapy to normal or high normal levels and the long chain metabolites further increased after one month of therapy (Table). A follow up small bowel biopsy on the 32nd day of zinc therapy showed normal histology under light microscopy. On electron microscopy the cytoplasm of Paneth cells contained numerous structurally normal secretory granules with only occasional filamentous inclusions (Fig. 2b).

\section{Methods}

Small bowel biopsies were obtained using a Crosby capsule from the fourth part of the duodenum under fluoroscopic control. Specimens for light and electron microscopy were processed using standard methods. Plasma zinc was measured using atomic absorption spectrophotometry. ${ }^{5}$ Preprandial plasma phospholipid composition was determined by capillary gas liquid chromatography.

\section{Discussion}

Our patient presented with chronic diarrhoea, poor weight gain, irritability and perianal ulceration, together suggestive of a zinc deficiency state. The marked ultrastructural abnormalities of the small intestinal Paneth cells encouraged a trial of oral zinc supplements in the face of normal levels of serum zinc and alkaline phosphatase, parameters most commonly measured in the direct and indirect assessment of zinc status?

The clinical syndrome of acrodermatitis enteropathica results from an as yet uncertain defect in intestinal absorption of zinc. ' A mucosal or pan- creatic zinc binding ligand of abnormal affinity has been implicated. This specific absorptive defect is overcome by giving elemental zinc in pharmacological doses or by ingesting zinc bound to another ligand as in the case with breast milk zinc. ${ }^{1+}$ In an untreated patient serum zinc levels are usually, but not always low. ${ }^{34}$ The histological appearance of small intestinal mucosa has been variable. Non-specific villous flattening and an inflammatory cell infiltrate have been described, ${ }^{*}$ but light microscopy may also be entirely normal." Abnormal Paneth cell inclusions, however, have been a consistent finding on electron microscopy. " "1"

This ultrastructural abnormality appears not to be primary, but rather to disappear with zinc therapy." Similar changes have been observed in rats rendered zinc deficient." Lombeck et al report an absence of such Paneth cell inclusions in small intestinal mucosa taken from normal subjects or from individuals with other intestinal disease. "' Our experience also suggests that this ultrastructural change is specific for zinc deficiency. Electron microscopy, performed routinely on all duodenal biopsies at the Hospital for Sick Chidren, has never revealed Paneth cell inclusions in patients with coeliac disease, post-infectious enteropathy, microvillous inclusion disease or normal intestinal mucosa. Apart from acrodermatitis enteropathica, only one other child with unexplained, probably congenital total villous atrophy, has displayed this ultrastructural aberration, and he, transiently, at the time when he may well have been zinc deficient. Bohane postulates ${ }^{2}$ that the high zinc content of the normal Paneth cell renders it particularly vulnerable to zinc deficiency of this trace metal. It may therefore be a sensitive indicator of body zinc status.

Zinc deficiency is thought to be associated with a reduced enteral absorption of unsaturated fatty acids and an impaired desaturation of linoleic and alphalinoleic acids to their long chain metabolites." patient showed zinc responsive alterations in essential fatty acid metabolism (Table) as previously noted in classical acrodermatitis enteropathica. "The increase in serum levels of essential fatty acids and their long chain metabolites had begun after only five days of oral zinc supplementation, thus preceding improvement in many of the clinical signs and symptoms. A low availability of essential fatty acids may play a role in the pathogenesis of acrodermatitis enteropathicarelated symptoms such as eczematoid dermatitis and susceptibility to infections.

Defective neutrophil chemotaxis has been reported in acrodermatitis enteropathica, ${ }^{1.3}$ but the intermittent neutropenia observed in our patient before zinc therapy is an unexplained observation.

Acrodermatitis enteropathica with normal serum 
zinc levels has hitherto been diagnosed solely by persistence of typical symptoms without treatment and a clinical response to zinc therapy. ${ }^{3+}$ The authors of the original case reports, in attempting to reconcile the normal zinc levels, have postulated a defect in zinc release at the peripheral active site..$^{3}$ If indeed an abnormal intestinal or pancreatic zinc binding ligand is responsible for the zinc deficiency state of classical acrodermatitis enteropathica, ' genetic heterogeneity might allow for a serum ligand with preferential zinc binding in variant acrodermatitis enteropathica. Total zinc content of serum could then be normal but a lower fraction would be bound to ablumin and therefore exchangeable. Others deny the necessity to invoke a disease variant with different pathophysiology, arguing that turnover from peripheral tissues may simply be enough to maintain the relatively small peripheral plasma zinc pool. ' Consistently normal plasma zinc levels have been documented in patients with mild, but nonetheless symptomatic, zinc deficiency. ${ }^{14}$

It is because serum zinc does not always reliably reflect body zinc status that other direct measurements in hair, $24 \mathrm{~h}$ urine and more recently leukocytes are often suggested.? Alkaline phosphatase, one of the over 40 zinc dependent metalloenzymes, is the most commonly used indirect parameter of zinc deficiency. The normal range for infants is very wide (vide supra). Although within this normal range at the time of our tentative diagnosis of acrodermatitis enteropathica, our patient's alkaline phosphatase subsequently rose with zinc therapy to a level which was perhaps truly 'normal' for him.

Our observations and laboratory data strengthen the not always accepted contention that acrodermatitis enteropathica can be associated with normal serum zinc levels.' Our case report demonstrates the usefulness of electron microscopy of a duodenal biopsy and serial fatty acid determinations in corraborating an otherwise empiric diagnosis.

\section{References}

1 Aggett PJ. Acrodermatitis enteropathica. J Inherit Metab Dis 1983; 6 (suppl 1): 39-43.

2 Bohane TD, Cutz E, Hamilton JR, Gall DG. Acrodermatitis enteropathica, zinc, and the pancth cell. Gastroenterology 1977; 73: 587-92.

3 Garretts M. Molokhia M. Acrodermatitis enteropathica without hypozincemia. J Pediatr 1977; 91: 492-4.

4 Kricgler I, Evans GW, Zelkowitz PS. Zinc dependency as a cause of chronic diarrhea in variant acrodermatitis enteropathica. Pediatrics 1982: 69: 773-7.

5 Pekarek RS, Beisel WR. Bartelloni PJ, et al. Determination of serum zinc concentration in normal adult subjects by atomic absorption spectrophotometry. $\mathrm{Am} \mathrm{J}$ Clin Pathol 1972; 57: 506-10.

6 Koletzko B, Bretschneider A, Bremer HJ. Fatty acid composition of plasma lipids in acrodermatitis enteropathica before and after zinc supplementation. Eur $J$ Pediatr 1985; 143: 310-4.

7 Aggett PJ, Harries JT. Current status of zinc in health and disease states. Arch Dis Child 1979; 54: 909-17.

8 Kelly R, Davidson GP, Townley RRW, Campbell PE. Reversible intestinal mucosal abnormality in acrodermatitis enteropathica. Arch Dis Child 1976; 51: 21922.

9 Gwyn-Jones J, Elmes ME, Aggett PJ, Harries JT. The effect of zinc therapy on lysosomal inclusion bodics in intestinal epithelial cells in acrodermatitis enteropathica. Pediatr Res 1983; 17: 354-7.

10 Lombeck I, von Bassewitz DB, Becker K, et al. Ultrastructural findings in acrodermatitis enteropathica. Pediatr Res 1974: 8: 82-8.

11 Oho HF, Weitz H. Elektronenmikroskopische untersuchungen an paneth-zellen der ratte unter zinkarmer. Diat Beitr Pathol 1972; 145: 336-49.

12 Cunnane SC. Role of zinc in lipid and fatty acid metabolism and in membranes. Prog Food Nutr Sci 1988; 12: 151-8.

13 Weston WL, Huff JC, Humbert JR, et al. Zinc correction of defective chemotaxis in acrodermatitis enteropathica. Arch Dermatol 1977; 113: 422-5.

14 Prasad AS. Zinc in growth and development and spectrum of human zinc deficiency. J Am Coll Nutr 1988 ; 7: 377-84. 